\title{
Nitrogen Fixation by the Rumen Contents of Sheep
}

\author{
By K. JONES AND J. G. THOMAS \\ Department of Biological Sciences, University of Lancaster, Lancaster LA I $4 Y Q$
}

(Received 16 November 1973; revised 17 June 1974)

SUMMAR Y

\begin{abstract}
Assays using ${ }^{15} \mathrm{~N}_{2}$ and acetylene reduction showed that bacteria in the sheep rumen can fix atmospheric nitrogen. These bacteria are ingested when sheep are at pasture or provided with fresh, non-sterile, food. A permanent nitrogen-fixing microflora does not develop in the rumen. The addition of nitrogen-fixing bacteria to sheep rumina coupled with additional carbohydrate (I0\% molasses) in the feed increased the nitrogen-fixing capacity from $30 \mathrm{mg} \mathrm{N}$ to $800 \mathrm{mg} \mathrm{N}$ fixed/rumen/day.
\end{abstract}

\section{INTRODUCTION}

Nitrogen fixation can occur in the rumen of various animals (Toth, I948; Hardy, Holstein, Jackson \& Burns, I968; Elleway, Sabine \& Nicholas, 1971; Granhall \& Ciszuk, 1971; Postgate, 1971; Hobson, Summers, Postgate \& Ware, 1973) but the acetylene reduction assay indicated that the amounts were too low to be of significance to the animals. Elleway et al. (197I) suggested that sheep fed on diets low in nitrogen may benefit from nitrogen fixation in the rumen. Moisio, Kreula \& Virtanen (I969) passed ${ }^{15} \mathrm{~N}$-labelled nitrogen gas directly into the rumen of a cow but found no fixation.

The bacteria responsible may be indigenous to the rumen or ingested with animal foodstuffs: several genera amongst the rumen microflora include species which fix nitrogen (Hungate, I966), and nitrogen fixers are found on leaves (Ruinen, I965; Jones, 1970). The latter might fix nitrogen in the conditions of low oxygen concentration and high carbohydrate availability in the rumen.

We compared nitrogen fixation by the indigenous microflora in the rumen contents of sheep fed on sterilized feed and at pasture.

To obtain some idea of the potential for nitrogen fixation in the rumen, molasses and a continual supply of nitrogen-fixing bacteria were added to the diet of sheep.

\section{METHODS}

Animals. The experimental animals were cross-bred wethers (Dalesbred and Suffolk) fitted with rumen fistulas. They had been confined to metabolism cages and fed with commercially produced grass nuts sterilized by heating at $120^{\circ} \mathrm{C}$ for at least 30 min during manufacture (Vitagrass Farms Ltd, Holker, Cumbria, containing 3.10\% $\mathrm{N}$ and $60 \%$ digestible organic matter as a percentage of dry matter).

Samples of rumen contents were removed through permanent fistulas using the method described by Alexander \& McGowan (I966). The samples were diluted I:4 with isotonic phosphate buffer (McDougall, I948) and used immediately for acetylene reduction.

Culturing of bacteria. Nitrogen-fixing bacteria, isolated from the rumen, were grown on agar slopes of nitrogen-free media (Norris, 1959) at $37^{\circ} \mathrm{C}$ in $20 \mathrm{ml}$ Universal bottles closed 
Table I. Effect of diet on nitrogen fixation by the rumen contents of sheep

Diet

Sterile grass nuts

Lolium pasture

Sterile grass nuts + Festuca|Puccinellia

\begin{tabular}{|c|c|}
\hline \multicolumn{2}{|c|}{ Nitrogen fixed ${ }^{*}(\mu \mathrm{g} \mathrm{N} / \mathrm{g} / 24 \mathrm{~h})$} \\
\hline Dry rumen content & Rumen N \\
\hline $\begin{array}{l}0 \\
6.69\end{array}$ & $\begin{array}{c}0 \\
24 r \cdot 0\end{array}$ \\
\hline $4 \cdot 30$ & 185.0 \\
\hline
\end{tabular}

* The amount of nitrogen fixed was calculated from the theoretical value ${ }_{3} \mathrm{C}_{2} \mathrm{H}_{2} \equiv \mathrm{I} \mathrm{N} \mathrm{N}_{2}$.

Table 2. Nitrogen fixation by rumen contents of sheep at pasture and when fed sterile grass

The enrichment of unexposed rumen contents was $0.3560 \pm 0.0038$ atom $\%{ }^{15} \mathrm{~N}(5 \%$ confidence limit $)$.

Diet

Lolium perenne pasture

Sterile grass nuts
Atmosphere in flask

Atmospheric

Anaerobic

Atmospheric

Anaerobic

${ }^{15} \mathrm{~N}$-enrichment
(atom $\%{ }^{15} \mathrm{~N}$ excess)
$0.0140 \pm 0.0036$
$0.0160 \pm 0.0020$
0
0

Nitrogen fixed ( $\mu \mathrm{g} \mathrm{N} / \mathrm{g}$ rumen $\mathrm{N} / 24$ h)

$52 \cdot 0$ $59^{\circ} 0$

o

0

with serum caps. After evacuation the bottles were filled with an atmosphere of nitrogen containing $0.02 \%$ carbon dioxide.

Acetylene reduction. This was measured in Universal bottles $(20 \mathrm{ml})$ or bijou bottles $(7 \mathrm{ml})$ with serum caps. Rumen samples (Io $\mathrm{ml}$ ) were incubated at atmospheric oxygen levels (preliminary experiments showed that there were no differences in acetylene reduction when rumen samples were incubated aerobically or anaerobically), and the isolated bacteria anaerobically. Acetylene ( $\mathrm{I} \mathrm{ml}$ ) was added to the bottles which were incubated at $37{ }^{\circ} \mathrm{C}$. After $24 \mathrm{~h}$, I ml samples of gas were injected into a Varian Aerograph series 1400 gas chromatograph with a flame ionization detector, and the amounts of ethylene measured by using a stainless steel column, $2.74 \mathrm{~m} \times 2.5 \mathrm{~mm}$, packed with Poropak $\mathrm{R}$ and an oven temperature of $50{ }^{\circ} \mathrm{C}$ with nitrogen carrier gas flowing at $30 \mathrm{ml} / \mathrm{min}$.

${ }^{15} \mathrm{~N}$ experiments. Rumen and grass-soil samples were gassed anaerobically in $150 \mathrm{ml}$ Quickfit flasks with argon containing carbon dioxide $(0.02 \%)$ and nitrogen ( $5 \mathrm{ml}$ labelled to 90 atom $\%{ }^{15} \mathrm{~N}$ excess). Rumen samples were incubated at $37^{\circ} \mathrm{C}$ for 3 days. Flasks containing grass and adhering soil were treated similarly except that the gas contained 10\% oxygen, and they were incubated in the light at $20{ }^{\circ} \mathrm{C}$ for 3 days.

${ }^{15} \mathrm{~N}$-enriched samples were digested by a micro-Kjeldahl digestion followed by alkaline steam distillation in a Markham still. The distillate was collected in $0.01 \mathrm{M}-\mathrm{HCl}$ and evaporated to $2 \mathrm{ml}$ for ${ }^{15} \mathrm{~N}$ analysis in an A.E.I. type M.S. IO mass spectrometer after conversion of ammonia to nitrogen gas with sodium hypobromite.

\section{RESULTS}

Nitrogen fixation by rumen contents

In the first experiment sheep were routinely fed on sterilized grass nuts; in the second they grazed perennial ryegrass (Lolium perenne, cultivar S23); and in the third they were fed on sterilized grass nuts supplemented with a mixture of Festuca rubra (L.) and Puccinellia 
Table $3 \cdot{ }^{15} \mathrm{~N}$-enrichment of grasses and soils exposed to ${ }^{15} \mathrm{~N}$

The enrichment of the biological standard was 0.362 atom $\%{ }^{15} \mathrm{~N}$.

\begin{tabular}{lccc} 
& \multicolumn{3}{c}{${ }^{15} \mathrm{~N}$-enrichment (atom $\%{ }^{15} \mathrm{~N}$ excess) } \\
\cline { 2 - 4 } Grass & Soil & Roots & Leaves \\
Lolium & 0.010 & 0.015 & 0.018 \\
Puccinellia & 0.006 & 0.056 & 0.022 \\
Festuca & 0.015 & 0.015 & 0.002
\end{tabular}

Table 4. Nitrogen fixation in soils amended with $\mathrm{I} \%$ glucose

\begin{tabular}{|c|c|c|c|c|}
\hline \multirow[b]{2}{*}{ Origin of soil } & \multicolumn{2}{|c|}{$\begin{array}{c}{ }^{15} \mathrm{~N} \text {-enrichment } \\
\text { (atom } \%{ }^{15} \mathrm{~N} \text { excess) }\end{array}$} & \multicolumn{2}{|c|}{$\begin{array}{l}\text { Nitrogen fixed } \\
(\mathrm{mg} \mathrm{N} / \mathrm{g} \text { soil } \mathrm{N})\end{array}$} \\
\hline & - Glucose & + Glucose & - Glucose & + Glucose \\
\hline $\begin{array}{l}\text { Lolium } \\
\text { Puccinellia }\end{array}$ & $\begin{array}{l}0.010 \\
0.006\end{array}$ & $\begin{array}{l}0.110 \\
0.902\end{array}$ & $\begin{array}{l}\text { O.III I } \\
0.067\end{array}$ & $\begin{array}{r}\mathrm{I} \cdot 23 \\
10 \cdot 00\end{array}$ \\
\hline Festuca & 0.015 & 0.170 & $0 \cdot 167$ & I. 90 \\
\hline
\end{tabular}

Table 5. Nitrogen fixation in the rumen of sheep fed a mixture of sterile grass nuts and Festuca/Puccinellia salt marsh grass

\begin{tabular}{rlcc}
\multicolumn{1}{c}{ Day } & \multicolumn{1}{c}{ Diet } & $\mu \mathrm{g} / \mathrm{g}$ dry rumen & $\mu \mathrm{g} / \mathrm{g}$ rumen N \\
0 & Grass nuts & 0 & 0 \\
3 & Salt marsh grasses for 3 days & $4 \cdot 3$ & $185 \cdot 0$ \\
I I & Salt marsh grasses for 7 days and 4 days on grass nuts & $18 \cdot 0$ & $772 \cdot 0$ \\
I 8 & 7 more days on grass nuts & $8 \cdot 4$ & $364 \cdot 0$ \\
25 & 7 more days on grass nuts & 0 & 0
\end{tabular}

maritima (Huds.) Parl. collected from a salt marsh. After several days on these diets the rumen contents were tested for acetylene reproduction. Nitrogenase activity was only present in the rumina of sheep fed with fresh grass (Table I) and this was confirmed using ${ }^{15} \mathrm{~N}_{2}$ (Table 2). This suggests that nitrogen-fixing bacteria in the rumen originated from the grasses or from soil contaminating the grasses. There was no difference in nitrogen fixation or acetylene reduction between rumen samples incubated aerobically or anaerobically.

When grasses and surrounding soil were exposed to an atmosphere containing ${ }^{15} \mathrm{~N}_{2}$ and leaves, roots and soil were analysed separately for ${ }^{15} \mathrm{~N}$ enrichment, all samples proved to be slightly labelled (Table 3). Therefore either the soil, roots and leaves of the grasses have nitrogen-fixing bacteria associated with them, or bacteria in the soil or on the roots fix nitrogen, which is taken up by the roots and translocated to the leaves. In Puccinellia there is a pronounced stimulation of nitrogen fixation in the rhizosphere as the roots were more highly labelled than the surrounding soil. The presence of nitrogen-fixing bacteria was clearly demonstrated when glucose was added to the soil (Table 4).

To discover whether nitrogen-fixing bacteria ingested with the grass become permanent residents in the rumen, sheep were fed with salt marsh grasses and then returned to their normal diet of sterile grass nuts. The nitrogen-fixing capacity of the rumen was tested at regular intervals. Nitrogenase activity was not present until fresh grass was included in the diet and ceased within 18 days of reverting to a diet of sterile grass (Table 5). The nitrogenfixing bacteria did not form a permanent population within the rumen. 
Table 6. The effect of molasses (10 \%, w/w, in grass nuts) on nitrogen fixation by rumen contents to which nitrogen-fixing bacteria had been added

\begin{tabular}{ccc} 
& Nitrogen fixed ${ }^{*}(\mathrm{mg} \mathrm{N} / \mathrm{g}$ rumen N/day) \\
\cline { 2 - 3 } & 0 & - Molasses \\
0 & $0.81(8.33 \%)$ & 0 \\
1 & $3.68(2.92 \%)$ & $1.38(9.88 \%)$ \\
2 & $5.70(5.01 \%)$ & $0.63(5.26 \%)$ \\
4 & $9.21(6.88 \%)$ & $1.83(3.62 \%)$ \\
9 & $18.90(7.71 \%)$ & $2.67(4.12 \%)$ \\
16 & $3.31(9.16 \%)$
\end{tabular}

* The amount of nitrogen fixed was calculated using ${ }_{3} \mathrm{C}_{2} \mathrm{H}_{2} \equiv \mathrm{I} \mathrm{N}_{2}$. The values given are the means derived from 16 replicates from 2 sheep for each treatment; standard errors, as percentages of the mean, are given in parentheses.

\section{The effect of adding molasses and nitrogen-fixing bacteria}

To find how much nitrogen can be fixed in the sheep rumen, we added a readily available supply of carbohydrate and nitrogen-fixing bacteria to the diet of sterile grass nuts. Half the sheep had molasses (10\%, w/w) added to the grass nuts. All sheep were provided daily with a culture of actively fixing Bacillus macerans ( $10 \mathrm{ml}$ ) through the fistulas (bacterial cultures were grown in Universal bottles for 3 days in $\mathrm{N}$-free liquid media). Samples of rumen contents were tested for acetylene reduction at the beginning of the experiment and at regular intervals (rumen samples which were tested for acetylene reduction were taken before the addition of the bacteria). Acetylene reduction increased until day 16 and much more activity was obtained when molasses was included in the diet (Table 6). The addition of bacteria and molasses after the first 16 days did not further increase the amounts of nitrogen fixed in the rumen.

\section{DISCUSSION}

Nitrogen fixation in the rumen is apparently accomplished by bacteria ingested in the diet. It is probable, therefore, that great differences in fixation rate will occur between animals on different diets. If one makes the assumption that the average sheep takes in $40 \mathrm{~g}$ nitrogen per day, the results described above show a maximum fixation rate for sheep at pasture of $0.8 \mathrm{mg} \mathrm{N} / \mathrm{g}$ rumen $\mathrm{N} /$ day, or approximately $32 \mathrm{mg} / \mathrm{sheep}$ rumen/day. This compares with I $\mathrm{mg} \mathrm{N}$ fixed/bovine rumen/day (Elleway et al. I97I) or Io mg (Hardy et al. 1968), and with $0.4 \mathrm{mg}$ in sheep rumen (Hobson et al. 1973).

Under grazing conditions, fixation rates of approximately $8 \mathrm{mg} \mathrm{N} / \mathrm{rumen} /$ day were obtained for Lolium and $6 \mathrm{mg}$ for Festuca/Puccinellia. These levels are of little practical significance to the nutrition of the sheep, at best accounting for only $0 . \mathrm{I} \%$ of the daily nitrogen requirement. However, the activity was increased by adding a daily supply of nitrogen-fixing bacteria to the sheep diet and by including an extra source of carbohydrate (I0 $\%, \mathrm{w} / \mathrm{w}$, molasses). The maximum value reached was $18.9 \mathrm{mg} \mathrm{N} / \mathrm{g}$ rumen $\mathrm{N} /$ day, which is equivalent to about $750 \mathrm{mg} \mathrm{N}$ fixed/sheep/day. Thus nitrogen fixation in the rumen could be of value when the diet is low in nitrogen - many pastures contain as little as $5 \%$ crude protein and cereals may contain only 8 to $10 \%$. Under such conditions the fixation rates reported here possibly account for $6 \%$ of the total nitrogen intake.

Bacillus macerans, isolated from the rumen contents of sheep fed on salt marsh grasses, fixes most nitrogen under anaerobic or micro-aerophilic conditions and may contribute fixed nitrogen both to the sheep and to the salt marsh (Jones, 1974). 
The authors acknowledge the technical assistance given by $\mathrm{Mr}$ J. Davies and $\mathrm{Mr} \mathrm{D}$. Renshaw during this project.

\section{REFERENCES}

Alexander, R. H. \& MCGowan, M. (Ig66). The routine determination of in vitro digestibility of organic matter in forages. An investigation of problems associated with continuous large scale operation. Journal of the British Grassland Society 2I, I40-I 47.

Elleway, R. F., Sabine, J. R. \& Nicholas, D. J. D. (1971). Acetylene reduction by rumen microflora. Archiv für Mikrobiologie 76, 277-29I.

Granhall, U. \& CiszuK, P. (1971). Nitrogen fixation in rumen contents indicated by the acetylene reduction test. Journal of General Microbiology 65, 9I-93.

Hardy, R. W. F., Holstein, R. D., Jackson, E. K. \& Burns, R. C. (I968). The acetylene-ethylene assay for nitrogen fixation: laboratory and field evaluation. Plant Physiology 43, I1 85-1207.

Hobson, P. N., Summers, R., Postgate, J. R. \& Ware, D. A. (1973). Nitrogen fixation in the rumen of living sheep. Journal of General Microbiology 77, 225-226.

Hungate, R. E. (1966). The Rumen and its Microbes. London: Academic Press.

JONEs, K. (1970). Nitrogen fixation in the phyllosphere of the Douglas Fir, Pseudotsuga douglasii. Annals of Botany 34, 239-244.

JONES, K. (1974). Nitrogen fixation in a salt marsh. Journal of Ecology 62, 583-595.

McDougall, E. I. (1948). Studies on ruminant saliva. I. The composition and output of sheep's saliva. Biochemical Journal 43, 99-109.

Moisio, R., Kreula, M. \& Virtanen, A. E. (1969). Experiments on nitrogen fixation in cow's rumen. Suomen Kemistilehti B42, 432-433.

NorRIS, J. R. (1959). The isolation and identification of azotobacters. Laboratory Practice 8, 239-243.

Postgate, J. R. (I97I). Biochemical and physiological studies with free-living, nitrogen-fixing bacteria. Plant and Soil, special volume, 55I-559.

Ruinen, J. (I965). The Phyllosphere. III. Nitrogen fixation in the phyllosphere. Plant and Soil 22, 375-394.

ToтH, L. (1948). Nitrogen fixing microorganisms in the alimentary canal of herbivorous farm animals. Experientia 4, 395-396. 